\title{
Selective Sorbent Enrichment of Nickel Ions from Aqueous Solutions using a Hierarchically Hybrid Organic-Inorganic Polymer Based on Double Imprinting Concept
}

\author{
Letícia Ramos Nacano, ${ }^{a}$ Mariana Gava Segatelli ${ }^{a}$ and César Ricardo Teixeira Tarley ${ }^{*, a, b}$ \\ ${ }^{a}$ Departamento de Ciências Exatas, Universidade Federal de Alfenas (Unifal-MG), \\ Rua Gabriel Monteiro da Silva, 700, 37130-000 Alfenas-MG, Brazil \\ ${ }^{b}$ Departamento de Química Analítica, Instituto Nacional de Ciência e Tecnologia (INCT) \\ de Bioanalítica, Instituto de Química, Universidade Estadual de Campinas (Unicamp), \\ Cidade Universitária Zeferino Vaz s/n, 13083-970 Campinas-SP, Brazil
}

\begin{abstract}
Este estudo envolve a preparação de um polímero orgânico-inorgânico impresso com íon (IIP) para o enriquecimento seletivo de $\mathrm{Ni}^{2+}$ em soluções aquosas com posterior determinação por GF AAS. A rede polimérica híbrida foi preparada a partir de uma mistura do monômero funcional, 2-aminoetil-3-aminobutilmetildimetoxissilano e tetraetoxissilano como agente de ligação cruzada, contendo $\mathrm{Ni}^{2+}$ e brometo de cetiltrimetilamônio como moldes. Os polímeros foram caracterizados por IV, TG e MEV. A capacidade máxima adsortiva do IIP para os íons $\mathrm{Ni}^{2+}$, determinada pelo modelo linear de Langmuir, foi de $5,44 \mathrm{mg} \mathrm{g}^{-1}$. Quando o coeficiente de seletividade iônica do IIP foi comparado com os coeficientes de seletividade do NIP (non imprinted polymer) e IIP2 (ion imprinted polymer na ausência do surfactante), a partir das misturas binárias de $\mathrm{Ni}^{2+} / \mathrm{Cu}^{2+}$, $\mathrm{Ni}^{2+} / \mathrm{Co}^{2+}, \mathrm{Ni}^{2+} / \mathrm{Cd}^{2+}$ e Ni ${ }^{2+} / \mathrm{Zn}^{2+}$, os respectivos valores do coeficiente de seletividade relativo ( $\mathrm{k}^{\prime}$ ) foram 36,54 e 3,55, 1,22 e 2,03, 4,43 e 1,42, 28,60 e 1,74, demonstrando maior seletividade do IIP para os íons $\mathrm{Ni}^{2+}$. O método proposto forneceu um limite de detecção de $0,16 \mu \mathrm{g} \mathrm{\textrm {L } ^ { - 1 }}$ e foi aplicado com sucesso na determinação de $\mathrm{Ni}^{2+}$ em amostras de águas enriquecidas e fitoterápico (Gingko Biloba) com valores satisfatórios de recuperação.
\end{abstract}

This study involves the preparation of an ion imprinted organic-inorganic polymer (IIP) for selective sorbent enrichment of $\mathrm{Ni}^{2+}$ from aqueous solutions with further determination by GF AAS. The hybrid polymeric network was prepared from a mixture of 2-aminoethyl-3aminobutylmethyldimethoxysilane as functional monomer, and tetraethoxysilane as crosslinking agent, containing $\mathrm{Ni}^{2+}$ and cetyltrimethylammonium bromide as templates. The polymers were characterized by IR, TG and SEM. The maximum adsorptive capacity of IIP towards $\mathrm{Ni}^{2+}$ ions, determined by linear Langmuir model, was found to be $5.44 \mathrm{mg} \mathrm{g}^{-1}$. When the selectivity coefficient of IIP was compared with the selectivity coefficient of NIP (non imprinted polymer) and IIP2 (ion imprinted polymer in the absence of surfactant), from the binary mixtures of $\mathrm{Ni}^{2+} / \mathrm{Cu}^{2+}, \mathrm{Ni}^{2+} / \mathrm{Co}^{2+}$, $\mathrm{Ni}^{2+} / \mathrm{Cd}^{2+}$ and $\mathrm{Ni}^{2+} / \mathrm{Zn}^{2+}$, values of relative selectivity coefficient $\left(\mathrm{k}^{\prime}\right)$ were 36.54 and $3.55,1.22$ and $2.03,4.43$ and 1.42, 28.60 and 1.74, respectively, demonstrating higher selectivity of IIP for $\mathrm{Ni}^{2+}$ ions. The proposed method provided a limit of detection of $0.16 \mu \mathrm{g} \mathrm{L}^{-1}$ and was successfully applied for $\mathrm{Ni}^{2+}$ determination in spiked water samples and in a phytoterapic product (Gingko Biloba) with satisfactory recovery values.

Keywords: nickel, Hierarchically Imprinted Polymer, GF AAS, enrichment

\section{Introduction}

Recent years have seen remarkable progress in the development of separation/preconcentration methodologies

*e-mail: ctarleyquim@yahoo.com.br for analysis of sample at low analyte levels, mainly for solving instrumental problems. Indeed, solid phase extraction (SPE) has been the most used technique for this purpose, due to its natural features such as high reproducibly, high preconcentration factor, ease of automation and easy regeneration of solid phase. ${ }^{1}$ A survey 
on the literature shows that the primary requirements to attain good performance of the SPE include quantitative sorption and elution, kinetically faster sorption and desorption, accessibility of analyte towards sites of sorbents and, mainly, selectivity. ${ }^{2}$ The selective analyte separation has not been properly achieved from analysis of real samples by using conventional solid sorbents, such as modified silica $\left(\mathrm{C}_{18}\right)$, chelating resins, unloaded polyurethane foam and activated carbon, thus being the main disadvantage of the SPE. ${ }^{3}$ Nevertheless, this drawback can successfully be overcome by using selective sorbents, which present specific recognition sites formed in synthetic materials by binding analyte with high specific sites of sorbent. ${ }^{4}$ These materials make use of chemical imprinting technology that provides selective recognition at molecular level of an analyte over closely related structural analogues. Molecularly imprinted polymers have been the most common approach of chemical imprinting technology and have found application in several analytical methods such as, chromatographic separation, sensors, solid phase extraction for sample clean-up and fluorescence spectroscopy. ${ }^{5}$ Based on simple specific memory effect created as a consequence of the shape and the position of functional group of the template molecules with those functional groups of sorbent, Nishide et al. ${ }^{4}$ in a similar way, proposed, for the first time, sorbent materials capable of recognizing metallic ions. The selectivity of these ion imprinted materials depends on the specificity of the ligand, coordination geometry, coordination number charges and sizes of the ions. ${ }^{6,7}$ Thus, it is of paramount importance the preparation of these materials for the development of selective sorbent enrichment methods for metallic ions. In fact, similarly to molecularly imprinting materials, ion imprinted materials find interesting applications in SPE, metal ion sensors and membranes separation of inorganics, but their use is significantly less exploited. Different approaches in synthesis of these sorbents can be adopted and mainly categorized as organic or hybrid organic-inorganic sorbents. In organic polymeric sorbents, the "memorized cavity" by means binding metal ion templates with those sites of organic monomers, can be achieved from different methods, such as crosslinking of bifunctional reagents with linear polymeric chains, chemical immobilization, surface imprinting and trapping. In order to get more information, the reader can refer to a review described by Rao et al. ${ }^{2}$ Regarding organic-inorganic polymeric sorbents, the conventional sol-gel process has widely been employed for the incorporation of the metal ion templates into rigid networks ${ }^{8}$, using tetraethoxisylane (TEOS) as the inorganic precursor and organic molecules as functional monomers. In addition, ion imprinted sorbents can also be prepared by surface imprinting technique, in which the silica gel surface is modified with organic molecules as functional monomers. ${ }^{9}$ Although these two conventional methods provide sorbents with attractive features, including high selectivity and absence of welling effect,,${ }^{9,10}$ both do not present a precise control of pore sizes and surface area. ${ }^{11}$ Moreover, especially for sol-gel process, the resulting materials exhibit reduced accessibility of the analyte towards linkage sites, promoting unfavorable adsorption/ dessorption kinetics. Therefore, improved hybrid organicinorganic sorbents with a precise control of not only adsorption sites but also with mesoporous structures have been developed by using surfactants during the synthesis. ${ }^{12}$ These sorbents are known as hierarchically imprinted organic-inorganic sorbents because they utilize the imprinting effect twice (metal ion template and surfactant). Their application as selective materials are still in early stages and have been limited only for copper, ${ }^{12}$ cadmium and mercury, ${ }^{13,14}$ whose functional employed groups have been (3-(2-aminoethylamino)-propyltrimethoxysilane) and $N$-[3-(trimethoxy-silyl)propyl]ethylenediamine (TPED).

Thus, in the present study, a hybrid organic-inorganic sorbent based on double imprinting concept was evaluated for selective retention of nickel ions from aqueous solution using 2-aminoethyl-3-aminobutylmethyldimethoxysilane (AAMDMS), as functional monomer. The sorbent was characterized by infrared spectroscopy, thermogravimetry (TG), scanning electron microscopy (SEM) and adsorption isotherms. In addition, it was compared with control polymers taking into account the relative selectivity coefficient (k'). Finally, by using the selective sorbent a reliable preconcentration method for nickel determination by GF AAS was developed and its feasibility was assessed by its application for analysis of water samples. The whole optimization procedure was performed by using factorial design and Doehlert matrix owing to its intrinsic advantages over univariate method. ${ }^{15}$

\section{Experimental}

\section{Instrumentation}

A graphite furnace atomic absorption spectrometer (GF AAS) (Zeiss AA55, Jena, Germany), equipped with deuterium lamp for background correction and a hollow cathode lamp as radiation source for nickel, was used. The hollow cathode lamp was operated at $5.0 \mathrm{~mA}$ and the wavelength was set at $232.0 \mathrm{~nm}$. Aliquots of $20 \mu \mathrm{L}$ of each sample and calibration solution using MPE 5 autosampler were directly injected into the pyrolytic graphite tube without L'vov platform with transversal heating. Argon 
99.99\% (White Martins, São Paulo, Brazil) was used as purge gas. A Shimadzu AA-6800 flame atomic absorption spectrometer (FAAS) (Shimadzu, Tokyo, Japan) was also used in this study. The $\mathrm{pH}$ values of samples were measured using a pH-meter (Scott, Cambridge UK), equipped with a glass-combination electrode. A peristaltic pump (Ismatec IPC-08, Glattzbrugg, Switzerland), furnished with Tygon ${ }^{\circledR}$ tubes, was used to propel all samples and reagent solutions. The morphology of all polymers was evaluated by scanning electron microscopy (SEM), using a JEOL JSM-6360 LV scanning electron microscope (Tokyo, Japan) with an electron acceleration voltage of $20 \mathrm{kV}$. The samples were previously coated by a thin layer of carbon followed by the $\mathrm{Au} / \mathrm{Pd}$ alloy in a Bal-Tec MED 020 equipment. Thermal analyses were performed in a TA Instruments TGA 2950 thermogravimetric analyzer (California, USA), where the polymers $\left(\mathrm{ca} .10 \mathrm{mg}\right.$ ) were heated from 30 up to $980{ }^{\circ} \mathrm{C}$, at a heating rate of $10{ }^{\circ} \mathrm{C} \mathrm{min}^{-1}$, under argon atmosphere. Infrared (IR) spectra were obtained in a Bomem Michelson MB-102 spectrometer. The experiments were carried out using $\mathrm{KBr}$ discs to prepare the polymer samples and the spectral range varied from 4000 to $400 \mathrm{~cm}^{-1}$. Sample decomposition was performed in a microwave oven (Milestone Microwave Laboratory System).

\section{Reagents and solutions}

The solutions were prepared with analytical grade chemical reagents as well as with water obtained from a Milli-Q purification system (Millipore, Bedford, MA, USA). In order to prevent metal contamination from laboratory glassware, it was kept $24 \mathrm{~h}$ in a $10 \% \mathrm{v} / \mathrm{v} \mathrm{HNO}_{3}$ solution. Tetraethoxysilane (TEOS) and 2-aminoethyl-3aminobutylmethyldimethoxysilane (AAMDMS) from Alfa Products were used in this study. Cetyltrimethylammonium bromide (CTAB) (Vetec, Brazil) was used without further purification. Nickel standard solutions were prepared daily by appropriate dilution of $1000 \mathrm{mg} \mathrm{L}^{-1}$ nickel solution (Merck, Darmstadt, Germany). Acetate, borate, amoniacal and phosphate buffers were prepared from their respective salts (Merck) without further purification. Ethanol of analytical grade was purchased from Merck. All solutions used in interference study containing the $\mathrm{Cu}^{2+}, \mathrm{Cd}^{2+}, \mathrm{Co}^{2+}$, $\mathrm{Sb}^{3+}, \mathrm{Pb}^{2+}, \mathrm{Mn}^{2+}, \mathrm{Zn}^{2+}$ foreign ions were prepared by dilution from Merck standard solutions at $1000 \mathrm{mg} \mathrm{L}^{-1}$.

\section{Preparation of hierarchically hybrid organic-inorganic polymer}

The synthetic route and the recognition mechanism of $\mathrm{Ni}^{2+}$ ions were based on literature with minor modification. ${ }^{13}$
In the first step, the complex formation was performed between $\mathrm{Ni}^{2+}$ ions and those binding sites (-NH- and $-\mathrm{NH}_{2}$ ) present in AAMDMS in the presence of CTAB. For this task, $0.550 \mathrm{~g}$ of $\mathrm{NiCl}_{2} .5 \mathrm{H}_{2} \mathrm{O}$ and $1.46 \mathrm{~g}$ of CTAB were dissolved in $40 \mathrm{~mL}$ of deionized water. To this mixture, $1.1 \mathrm{~g}$ of AAMDMS was added and magnetically stirred for $1 \mathrm{~h}$. Next, TEOS ( $4.0 \mathrm{~g}$ of TEOS was dissolved in $4 \mathrm{~mL}$ of methanol and stirred for $20 \mathrm{~min})$ and $\mathrm{NaOH}\left(1.0 \mathrm{~mol} \mathrm{~L}^{-1}\right.$, $7.6 \mathrm{~mL}$ ) were added to the mixture, which was stirred for 2 days at room temperature and, then, refluxed at $90{ }^{\circ} \mathrm{C}$ for 1 day. In this procedure, TEOS and AAMDMS were independently self-hydrolyzed and self-condensed to form the hybrid organic-inorganic polymer. The hydrolysis of TEOS and the copolymerization occur due to the presence of $\mathrm{NaOH}$. After the end of the synthesis, $\mathrm{Ni}^{2+}$ ion confined in the selective cavity and the surfactant incorporated in the sorbent were removed from successive washings with $2.0 \mathrm{~mol} \mathrm{~L}^{-1} \mathrm{HNO}_{3}$ and ethanol, respectively. The resulting polymer was exhaustively washed with deionized water, and dried at $100{ }^{\circ} \mathrm{C}$ for $4 \mathrm{~h}$ until use. In order to evaluate the selective features of the polymer as well as the effect of CTAB in the synthesis, the $\mathrm{Ni}^{2+}$ - imprinted polymer, defined here as IIP2, was also prepared using the same synthesis procedure, except by addition of CTAB. In addition, the control blank polymer, known as NIP (non imprinted polymer) was prepared in parallel without addition of $\mathrm{Ni}^{2+}$, however containing CTAB. These polymers (IIP, NIP and IIP2) were further characterized by SEM, thermogravimetry (TG) and IR.

General procedure for enrichment of nickel ions from water samples

The ion imprinted polymer (IIP) (100 mg) was packed into a minicolumn $(6.0 \times 1.0 \mathrm{~cm}$ i.d.), made of poly(vinyl chlorine) (PVC). Small amounts of glass wool were placed at both sides in order to prevent loss of the polymer during sample loading. Afterwards, the minicolumn was successively conditioned with $3.0 \mathrm{~mol} \mathrm{~L}^{-1} \mathrm{HNO}_{3}$ and deionized water. The method was based on off-line enrichment of $20.0 \mathrm{~mL}$ of sample previously buffered ( $\mathrm{pH}$ 8.4) with $0.43 \mathrm{~mol} \mathrm{~L}^{-1}$ borate buffer onto polymer at a flow rate of $5.0 \mathrm{~mL} \mathrm{~min}{ }^{-1}$. After preconcentration procedure, the elution step was carried out with $2.0 \mathrm{~mL}$ of $3.3 \mathrm{~mol} \mathrm{~L}^{-1} \mathrm{HNO}_{3}$ solution at a flow rate of $2.0 \mathrm{~mL} \mathrm{~min}^{-1}$. The eluate was collected into an autosampler cup and an aliquot of $20.0 \mu \mathrm{L}$ was introduced into graphite furnace without adding chemical modifier. All operation conditions of GF AAS were employed according to manufacturer's instructions. The measurements were evaluated by peak area of the absorbance signals. 


\section{Batch adsorption experiments}

Adsorption experiments were carried out in closed polyethylene flasks at room temperature, by putting $30 \mathrm{mg}$ of IIP in $20.0 \mathrm{~mL}$ of $\mathrm{Ni}^{2+}$ ions solutions with increasing concentration ranging from 3.0 up to $11.0 \mathrm{mg} \mathrm{L}^{-1}$. The value of optimum $\mathrm{pH}\left(\mathrm{pH} 8.4\right.$ in $0.43 \mathrm{~mol} \mathrm{~L}^{-1}$ borate buffer) adopted in these experiments was that previously optimized from minicolumn preconcentration procedure, while shaking time employed was $10 \mathrm{~min}$. After the shaking time, the concentration of $\mathrm{Ni}^{2+}$ in the supernatant was determined by FAAS. The amount of $\mathrm{Ni}^{2+}$ adsorption on the IIP was determined as the difference between the initial concentration and the equilibrium concentration (supernatant). In order to achieve the maximum adsorption capacity (MAC), all batch experimental data were fitted to the linear Langmuir isotherm model. ${ }^{16}$

\section{Optimization of enrichment method}

The selective sorbent enrichment procedure of nickel ions was optimized by using a $2^{5-1}$ fractional factorial design associated with Doehlert matrix. These techniques were adopted in this study because they enable the selection of optimal experimental procedures, helping to avoid trivial mistakes during the optimization. The possibilities of simultaneous study of several factors also facilitate the evaluation of interaction effects between the factors as well as allow us to attain the best sensitivity of the method. Those factors commonly studied, which play important role in the sorbent enrichment system were: sample $\mathrm{pH}$, eluent concentration (EC), buffer sample concentration (BC), enrichment flow rate (EFR) and mass of IIP. All assays were performed by enrichment of $20.0 \mathrm{~mL}$ of $10.0 \mu \mathrm{g} \mathrm{L}-1$ nickel solution. The analyses of experimental assays were processed using the STATISTICA software package (StatSoft, Tulsa, USA).

The eluent flow rate was fixed at $2.0 \mathrm{~mL} \mathrm{~min}^{-1}$. It must be emphasized that higher amounts than $200 \mathrm{mg}$ of polymer were avoided throughout the study, once this condition leads to leakage in the minicolumn, due to resulting overpressure.

\section{Evaluation of imprinting effect on the IIP}

In order to measure the specificity of the IIP towards $\mathrm{Ni}^{2+}$ ions, adsorption studies under competitive conditions in the presence of $\mathrm{Cu}^{2+}, \mathrm{Co}^{2+}, \mathrm{Cd}^{2+}$ and $\mathrm{Zn}^{2+}$ ions were performed. As it is predictable that in the presence of foreign ions a competition might start for those sites of IIP, the imprinting effect of IIP towards $\mathrm{Ni}^{2+}$ ions was investigated from competitive adsorption of binary mixtures of $\mathrm{Ni}^{2+} / \mathrm{Cu}^{2+}, \mathrm{Ni}^{2+} / \mathrm{Co}^{2+}, \mathrm{Ni}^{2+} / \mathrm{Cd}^{2+}, \mathrm{Ni}^{2+} / \mathrm{Zn}^{2+}$ onto IIP, IIP2 and NIP. For this task, batch experiments were carried out at room temperature, where $100 \mathrm{mg}$ of polymers were taken and stirred for $30 \mathrm{~min}$ in closed polyethylene flasks with $50 \mathrm{~mL}$ of binary mixtures, containing $5 \mathrm{mg} \mathrm{L}^{-1}$ of each metallic ion, buffered ( $\mathrm{pH} 8.4$ ) with $0.43 \mathrm{~mol} \mathrm{~L}^{-1}$ borate buffer ( $\mathrm{pH}$ was adopted here according to the optimization procedure). After this step, the supernatant was collected and the metallic ion amounts were determined by FAAS. Based on these assays, parameters related to the selective performance of sorbents, such as distribution coefficient $\left(\mathrm{K}_{\mathrm{d}}\right)$, selectivity coefficient $(\mathrm{k})$ and relative selectivity coefficient ( $\left.\mathrm{k}^{\prime}\right)$ were determined. Distribution coefficients of $\mathrm{Ni}^{2+}, \mathrm{Cu}^{2+}, \mathrm{Co}^{2+}, \mathrm{Cd}^{2+}$ and $\mathrm{Zn}^{2+}$ were calculated according to equation (1):

$\mathrm{K}_{\mathrm{d}}=\left[\frac{\left(\mathrm{C}_{\mathrm{i}}-\mathrm{C}_{\mathrm{f}}\right)}{\mathrm{C}_{\mathrm{f}}}\right] \mathrm{x} \frac{\mathrm{V}_{\mathrm{s}}(\mathrm{mL})}{\text { mass of IIP }(\mathrm{g})}$

where $\mathrm{C}_{\mathrm{i}}, \mathrm{C}_{\mathrm{f}}$ and $\mathrm{V}_{\mathrm{s}}$ represent the initial, final solution concentrations and the volume of the solution, respectively. The selectivity coefficient is defined as the ratio between the distribution coefficient for $\mathrm{Ni}^{2+}$ ions and the distribution coefficient for foreign ions. In order to make a comparison between $\mathrm{k}$ values of the imprinted polymer with those control polymers, i.e. the relative selectivity coefficient $\left(k^{\prime}\right)$, the following equation (2) was employed. This equation allows an estimation of the effect of imprinting on selectivity.

$\kappa^{\prime}=\frac{\kappa_{\text {imprinted }}}{\kappa_{\text {control }}}$

\section{Results and Discussion}

\section{Characterization of hierarchically hybrid organic- inorganic polymer}

IR spectra of IIP, NIP and IIP2 are illustrated in Figure 1. As it can be seen from the spectra, the vibrations of $\mathrm{OH}$ relative to adsorbed water were observed around 3440 and $1627 \mathrm{~cm}^{-1}$. The absorption around $1380 \mathrm{~cm}^{-1}$ is assigned to $\mathrm{CH}_{2}-\mathrm{N}$ vibrations and a stronger and broader peak can be observed from IIP and IIP2 spectra, in which this phenomenon may be explained by coordination between $-\mathrm{CH}_{2}-\mathrm{N}-$ and $\mathrm{Ni}^{2+}$ ions, still retained into the selective cavities of IIP. In fact, imprinted polymer has an inherent limitation in removal of total template from selective cavities. In the three spectra, the observed peaks around 1079 and $947 \mathrm{~cm}^{-1}$ are attributed to the stretching 


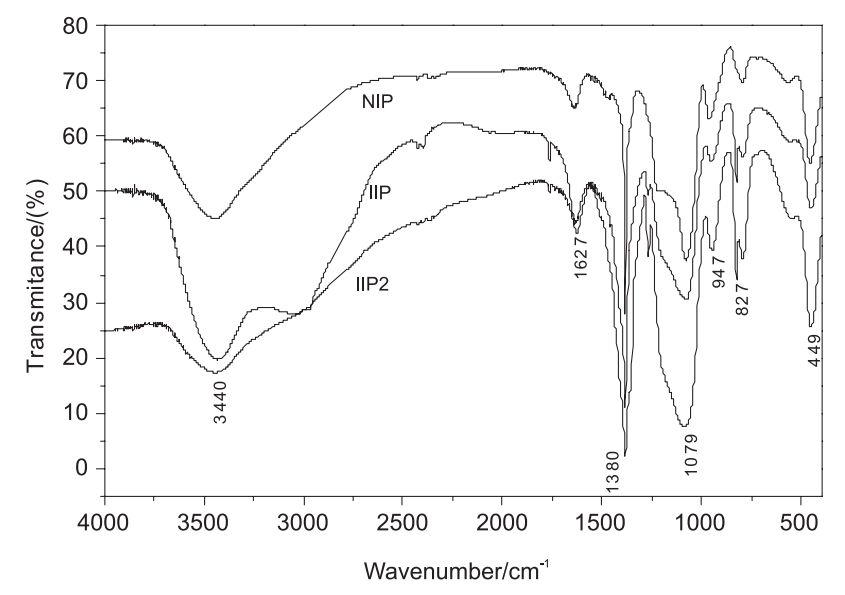

Figure 1. FT-IR spectra of polymers IIP, NIP and IIP2

of $\mathrm{Si}-\mathrm{O}-\mathrm{Si}$ and $\mathrm{Si}-\mathrm{O}-\mathrm{H}$ bonds, respectively, and the peaks around 827 and $449 \mathrm{~cm}^{-1}$ correspond to the $\mathrm{Si}-\mathrm{O}$ vibrations. The presence of two peaks of very low intensity around 3030 and $2969 \mathrm{~cm}^{-1}$ from IIP spectrum is attributed to the symmetry and asymmetry stretch vibration of $\mathrm{CH}_{2}$ of CTAB molecule. ${ }^{17}$

The morphology of the polymers is shown in Figures 2a-c. The images clearly shown the presence of pores in the IIP network and significant changes in the morphology of the IIP and NIP samples were observed. The IIP (Figure 2a) was found to have a larger surface area and particles with more uniform sizes than IIP2 (Figure 2c). This behavior demonstrates that the presence of surfactant in the synthesis may promote a better access of $\mathrm{Ni}^{2+}$ ions towards the selective cavity. On the other hand, NIP presented completely flat morphology, thus indicating that the presence of $\mathrm{Ni}^{2+}$ ions during the synthesis is fundamental and play a more important role than the surfactant for the formation of cavities and pores in the final product.

Thermogravimetric curves for the three polymers are shown in Figure 3. The polymers studied here are classified as polysilsesquioxane and their thermal degradation take place via scission and redistribution of $\mathrm{Si}-\mathrm{C}$ and $\mathrm{Si}-\mathrm{O}$ bonds, where high decomposition temperatures are observed, commonly accompanied by formation of silicon oxycarbide glasses. ${ }^{18}$ According to Figure 3, the initial weight loss from 25 up to around $180{ }^{\circ} \mathrm{C}$ was attributed to the physisorbed residual water and loss of volatile segments retained in the hybrid on account of incomplete polycondensation reactions of the residual silanol groups. For the IIP, a pronounced weight loss from 214 up to $223^{\circ} \mathrm{C}$ (ca. 49\%) was verified due to the thermal decomposition of the polymer and the subsequent weight loss (about $11 \%$ ) was detected in the range of $224-950{ }^{\circ} \mathrm{C}$, in which it was associated to the formation of silicon oxycarbide (a)

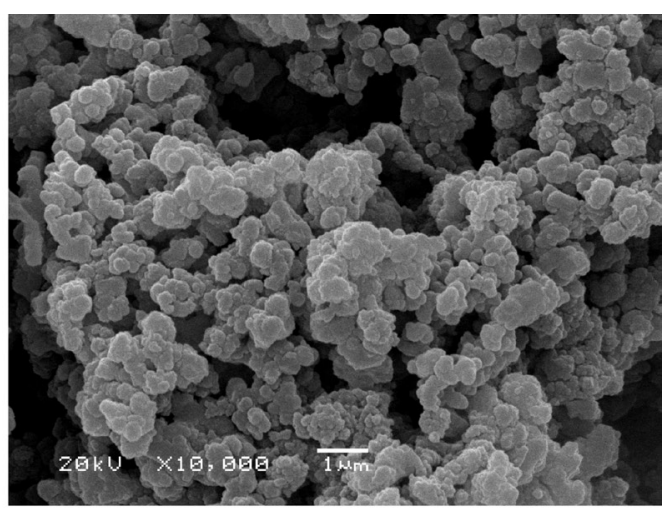

(b)

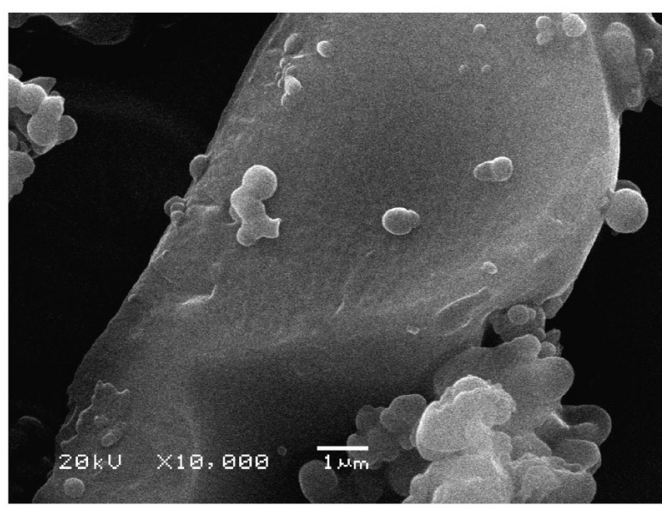

(c)

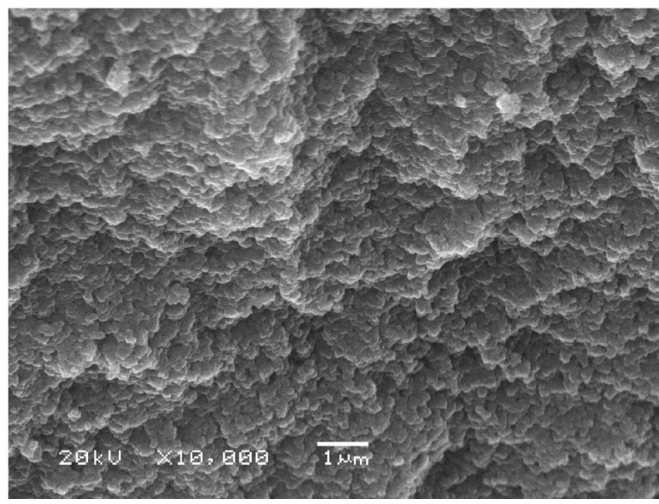

Figure 2. Scanning electron micrographs of (a) IIP, (b) NIP and (c) IIP2. The images were 10,000 amplified.

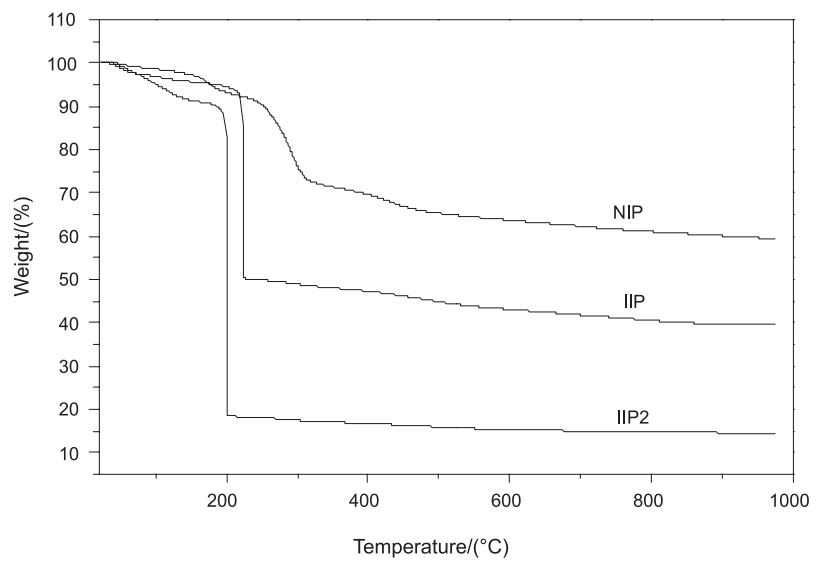

Figure 3. Thermogravimetric curves of polymers IIP, NIP and IIP2. 
glasses, which are stable at higher temperatures. A similar behavior was observed for the IIP2; however the polymer degradation was verified from 189 up to $201{ }^{\circ} \mathrm{C}$, with a weight loss of $81 \%$. Hence, the higher thermal stability and ceramic yield of IIP in relation to IIP2 indicated that there is a synergic effect between $\mathrm{Ni}^{2+}$ ions and the surfactant in the thermal stability of the IIP, in which it promoted a high crosslinking degree of the polymer. The thermal behavior of NIP showed a different degradation pattern when compared with IIP and IIP2. From 25 up to $248^{\circ} \mathrm{C}$, the weight loss (ca. $9 \%$ ) is attributed to physisorbed residual water and loss of volatile segments. Afterwards, the pyrolysis was obtained when the temperature varied from 248 up to $315^{\circ} \mathrm{C}$. In this step, the weight loss occurred by degradation of $\mathrm{Si}-\mathrm{C}$ bonds and redistribution of Si-O. Finally, the final step carried out up to $950{ }^{\circ} \mathrm{C}$ is assigned to the stable silicon oxycarbide glasses. A plausible explanation of the expressive difference of thermal stability and ceramic yield of NIP when compared with IIP and IIP2 is related to the porosity of the material. As already demonstrated, micrographs showed that NIP network do not exhibit porosity. Therefore, it is proposed that to the formation of densely packed crosslinked networks favors the increase of the initial temperature of polymer decomposition.

\section{Optimization of enrichment procedure}

Table 1 shows the factors, their levels and the analytical response for the $2^{5-1}$ fractional factorial design. For this design, the generator matrix Mass $=$ pH.EC.BC.EFR was adopted. The main effects and their interactions can be graphically represented from the Pareto chart (Figure 4). Based on main effect, the illustration shows that only the sample $\mathrm{pH}$ is statistically significant. Both buffer concentration and the eluent concentration are significant factors when analyzed from their interaction effects. On the other hand, the mass of IIP and the enrichment flow rate did not show to be significant for the proposed method. A mass of IIP of $100 \mathrm{mg}$ was, therefore, employed in this study for all other optimization steps. Even working with

Table 1. $2^{5-1}$ fractional factorial design and responses for the nickel enrichment on IIP

\begin{tabular}{|c|c|c|c|c|c|c|}
\hline \multirow{2}{*}{\multicolumn{4}{|c|}{ Factors }} & \multicolumn{3}{|c|}{ Levels } \\
\hline & & & & \multicolumn{2}{|c|}{ Minimum (-) } & Maximum (+) \\
\hline \multicolumn{4}{|c|}{$\mathrm{pH}$} & \multicolumn{2}{|c|}{5.0} & 8.0 \\
\hline \multicolumn{4}{|c|}{ Eluent concentration (EC) $\left(\mathrm{mol} \mathrm{L}^{-1}\right)$} & \multicolumn{2}{|c|}{2.0} & 4.0 \\
\hline \multicolumn{4}{|c|}{ Buffer concentration* $(\mathrm{BC})\left(\mathrm{mol} \mathrm{L}^{-1}\right)$} & \multicolumn{2}{|c|}{0.05} & 0.1 \\
\hline \multicolumn{4}{|c|}{ Enrichment flow rate (EFR) $\left(\mathrm{mL} \mathrm{min}^{-1}\right)$} & \multicolumn{2}{|c|}{5.0} & 10.0 \\
\hline \multicolumn{4}{|c|}{ Mass of IIP (mg) } & \multicolumn{2}{|c|}{100} & 200 \\
\hline Runs & $\mathrm{pH}$ & $\mathrm{EC}$ & $\mathrm{BC}$ & EFR & Mass & Response (peak area) \\
\hline 1 & - & - & - & - & + & $0.252 / 0.261$ \\
\hline 2 & + & - & - & - & - & $0.593 / 0.591$ \\
\hline 3 & - & + & - & - & - & $0.125 / 0.121$ \\
\hline 4 & + & + & - & - & + & $0.517 / 0.572$ \\
\hline 5 & - & - & + & - & - & $0.081 / 0.083$ \\
\hline 6 & + & - & + & - & + & $0.864 / 0.884$ \\
\hline 7 & - & + & + & - & + & $0.153 / 0.140$ \\
\hline 8 & + & + & + & - & - & $0.718 / 0.682$ \\
\hline 9 & - & - & - & + & - & $0.122 / 0.113$ \\
\hline 10 & + & - & - & + & + & $0.812 / 0.847$ \\
\hline 11 & - & + & - & + & + & $0.210 / 0.202$ \\
\hline 12 & + & + & - & + & - & $0.723 / 0.698$ \\
\hline 13 & - & - & + & + & + & $0.169 / 0.165$ \\
\hline 14 & + & - & + & + & - & $0.749 / 0.774$ \\
\hline 15 & - & + & + & + & - & $0.047 / 0.044$ \\
\hline 16 & + & + & + & + & + & $0.924 / 0.941$ \\
\hline
\end{tabular}

* Acetate/acetic acid buffer for $\mathrm{pH} 5.0$ and phosphate for $\mathrm{pH} 8.0$ 


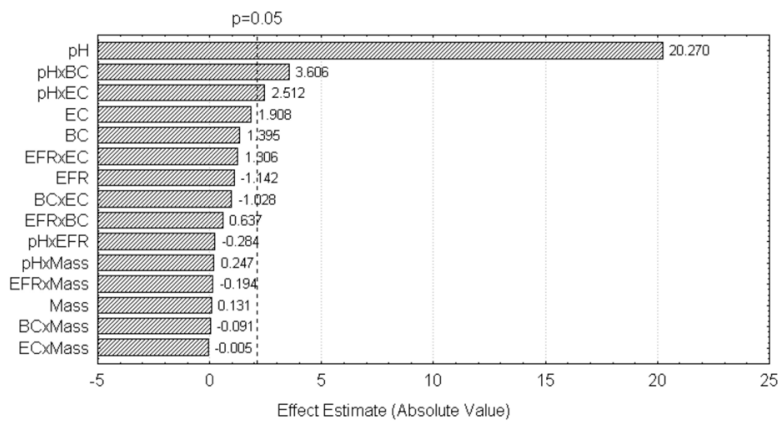

Figure 4. Pareto chart used for assessing the effect of factors on pre-concentration procedure. $\mathrm{EC}=$ eluent concentration; $\mathrm{BC}=$ buffer concentration; $\mathrm{EFR}=$ enrichment flow rate; Mass $=$ mass of IIP.

high enrichment flow rate $\left(10 \mathrm{~mL} \mathrm{~min}^{-1}\right)$, the analytical signal was satisfactory, indicating that the kinetic of mass transfer of $\mathrm{Ni}^{2+}$ towards selective sites of IIP is fast and independent of flow rate. Therefore, $10 \mathrm{~mL} \mathrm{~min}{ }^{-1}$ was chosen for subsequent studies.

An enhancement of $\mathrm{Ni}^{2+}$ adsorption at the IIP was noted by increasing the sample $\mathrm{pH}$ within the experimental domain (5.0 to 8.0). At lower $\mathrm{pH}$ values, the nitrogen atoms of the functional precursor are positively charged and, as a consequence, an electrostatic repulsion occurs with $\mathrm{Ni}^{2+}$ ions. In addition, it is interesting to note that the analytical response is increased when the sample $\mathrm{pH}$ and the buffer concentration are simultaneously increased. This observation can be evidenced by significant positive interaction effect (3.60). So, a higher analytical signal will be achieved by simultaneous increase in the sample $\mathrm{pH}$ and the buffer concentration levels and such conditions could never be achieved if a univariated optimization was used. In order to evaluate the effect of the eluent concentration, we can take into account the interaction between $\mathrm{pH}$ and $\mathrm{EC}$, which is positive and statistically significant (2.51). This result suggests the necessity of using acid concentrations higher than $2.0 \mathrm{~mol} \mathrm{~L}^{-1}$ to enhance the analytical signal as well as to avoid memory effect during the enrichment/ elution steps.

In order to find the optimum values for $\mathrm{pH}, \mathrm{EC}$ and $\mathrm{BC}$, a Doehlert matrix was used. Each factor has now a new minimum, maximum and central level that was chosen bearing in mind the results from $2^{5-1}$ fractional factorial design. The results obtained are shown in Table 2. From the analysis of these results by using analysis of variance (ANOVA) (Table 3), it can be concluded that the quadratic regression model is significant, once there is no lack of fit with a confidence interval of $95 \%\left[\mathrm{MS}_{\text {lof }} / \mathrm{MS}_{\mathrm{pe}}\right.$ (3.1224) is lower than critical $\left.F_{3,2}(19.16)\right]$. An observation of the response surfaces in Figure 5 allows us to obtain optimum values of the studied factors. Hence, based on these results, the following experimental conditions were optimized:
Table 2. Doehlert matrix employed for final optimization of $\mathrm{pH}$, eluent concentration and buffer concentration

\begin{tabular}{lcccc}
\hline Runs & $\mathrm{pH}$ & $\begin{array}{c}\mathrm{EC} \\
\left(\mathrm{mol} \mathrm{L}^{-1}\right)\end{array}$ & $\begin{array}{c}\mathrm{BC}^{*} \\
\left(\mathrm{~mol} \mathrm{~L}^{-1}\right)\end{array}$ & $\begin{array}{c}\text { Response } \\
(\text { peak area })\end{array}$ \\
\hline 1 & 8.0 & 3.0 & 0.275 & 0.898 \\
2 & 8.0 & 3.0 & 0.275 & 0.809 \\
3 & 8.0 & 3.0 & 0.275 & 0.760 \\
4 & 8.0 & 3.0 & 0.500 & 0.949 \\
5 & 10.0 & 3.0 & 0.387 & 0.395 \\
6 & 8.6 & 4.0 & 0.387 & 0.817 \\
7 & 8.0 & 3.0 & 0.050 & 0.369 \\
8 & 6.0 & 3.0 & 0.162 & 0.092 \\
9 & 7.3 & 2.0 & 0.162 & 0.430 \\
10 & 6.0 & 3.0 & 0.387 & 0.044 \\
11 & 7.3 & 2.0 & 0.387 & 0.541 \\
12 & 10.0 & 3.0 & 0.162 & 0.296 \\
13 & 9.3 & 2.0 & 0.275 & 0.298 \\
14 & 8.6 & 4.0 & 0.162 & 0.563 \\
15 & 6.6 & 4.0 & 0.275 & 0.298 \\
\hline
\end{tabular}

* Acetate/acetic acid buffer for $\mathrm{pH} 6.0$, phosphate for $\mathrm{pH}$ ranging from 6.6 up to 7.3 , borate for $\mathrm{pH} 8.6$ and amoniacal $\mathrm{pH}$ ranging from 9.3 up to 10.0

Table 3. Analysis of variance obtained from the Doehlert design shown in Table 2

\begin{tabular}{lccccc}
\hline Effects & SS & df & MS & $F$ & $p$ \\
\hline BC & 0.152447 & 1 & 0.152447 & 30.8300 & 0.030939 \\
BC $^{2}$ & 0.032070 & 1 & 0.032070 & 6.4857 & 0.125752 \\
$\mathrm{pH}$ & 0.098972 & 1 & 0.098972 & 20.0156 & 0.046504 \\
$\mathrm{pH}^{2}$ & 0.697517 & 1 & 0.697517 & 141.0618 & 0.007015 \\
$\mathrm{EC}$ & 0.024471 & 1 & 0.024471 & 4.9488 & 0.156093 \\
$\mathrm{EC}^{2}$ & 0.100422 & 1 & 0.100422 & 20.3088 & 0.045878 \\
$\mathrm{BC}^{\mathrm{pHH}}$ & 0.006072 & 1 & 0.006072 & 1.2279 & 0.383226 \\
$\mathrm{BC} . \mathrm{EC}$ & 0.001931 & 1 & 0.001931 & 0.3906 & 0.595790 \\
$\mathrm{pH} . \mathrm{EC}$ & 0.027032 & 1 & 0.027032 & 5.4668 & 0.144344 \\
Lack of fit (lof) & 0.046318 & 3 & 0.015439 & 3.1224 & 0.251945 \\
Pure error (pe) & 0.009890 & 2 & 0.004945 & & \\
Total SS & 1.159225 & 14 & & & \\
\hline
\end{tabular}

$\mathrm{R}^{2}=0.95151$ and $\mathrm{R}^{2}$ adjusted $=0.86424$

8.4 for $\mathrm{pH}, 0.43 \mathrm{~mol} \mathrm{~L}^{-1}$ for borate buffer concentration and $3.3 \mathrm{~mol} \mathrm{~L}^{-1}$ for eluent concentration.

\section{Batch adsorption experiments}

It is well established that to build adsorption isotherms, two important parameters must be optimized: sample $\mathrm{pH}$ and equilibrium time. Thus, as previously optimized, the 
(a)

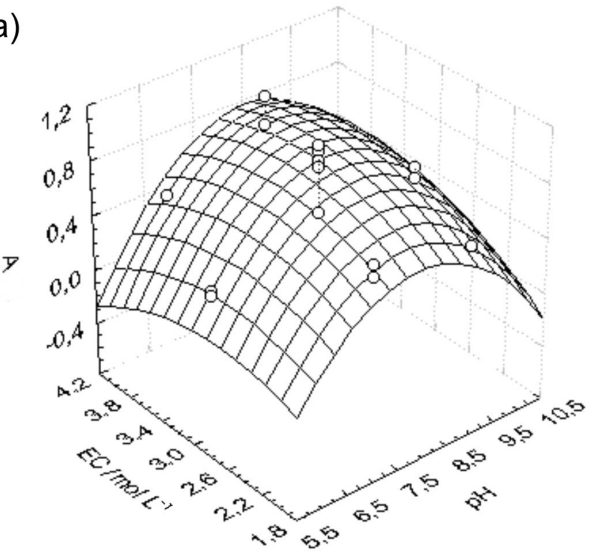

(b)

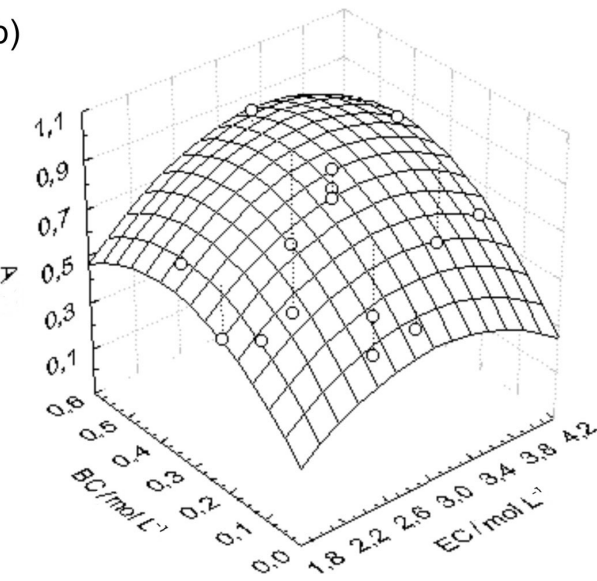

(c)

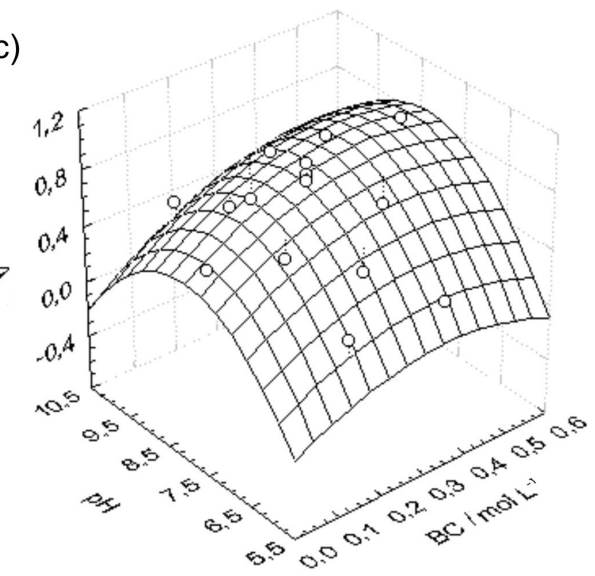

Figure 5. Surface response obtained from Doehlert matrix (a) EC x pH (b) $\mathrm{BC} \times \mathrm{EC}$ (c) $\mathrm{pH} \times \mathrm{BC}$.

optimum sample $\mathrm{pH}$ value of $\mathrm{Ni}^{2+}$ adsorption onto IIP was 8.4 , while 10 min of shaking time were sufficient for attaining the equilibrium time of $\mathrm{Ni}^{2+}$ between the solid and liquid phases (data not shown). By using these values, the adsorption isotherm of $\mathrm{Ni}^{2+}$ is illustrated in Figure 6(a). The experimental isotherm data were successfully fitted to the linear Langmuir isotherm model (Figure 6b), with coefficient of determination of 0.9962 . The maximum adsorbed amount of $\mathrm{Ni}^{2+}$ on the IIP was $5.44 \mathrm{mg} \mathrm{g}^{-1}$. This (a)

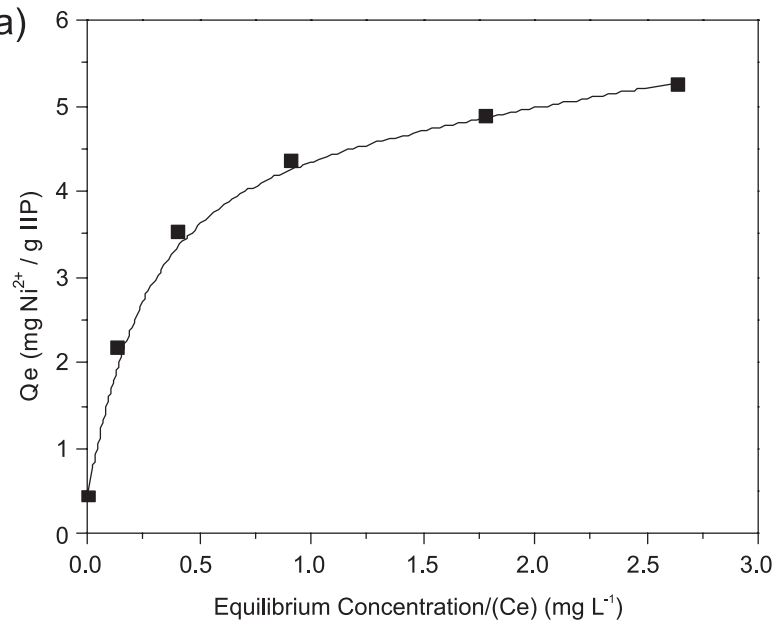

(b)

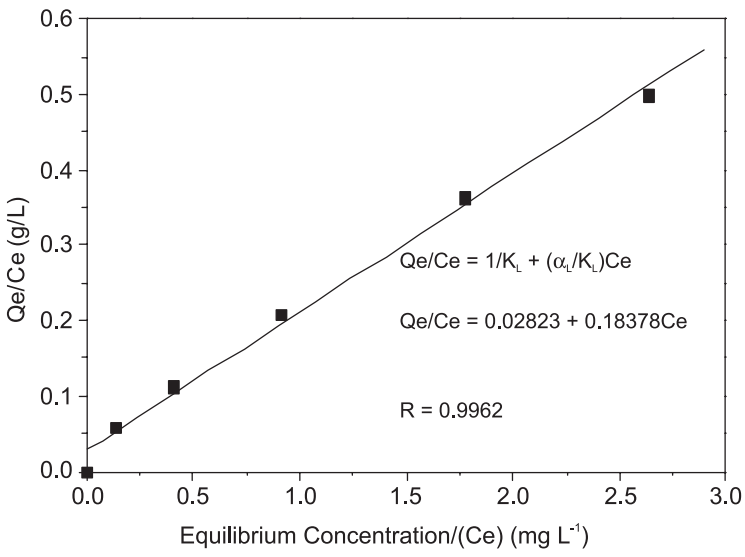

Figure 6. Adsorption isotherm of $\mathrm{Ni}^{2+}$ ions on IIP (a), Linear representation of Langmuir equation of $\mathrm{Ni}^{2+}$ with IIP.

result shows that the adsorption capacity of the hybrid organic-inorganic polymer towards $\mathrm{Ni}^{2+}$ ions is higher than others organic ion imprinted polymers previously published. ${ }^{19-21}$

\section{Evaluation of imprinting effect on the IIP}

Tables 4 and 5, show $\mathrm{K}_{\mathrm{d}}$, $\mathrm{k}$ and $\mathrm{k}$ ' values of $\mathrm{Cu}^{2+}$ (ionic radius $87.0 \mathrm{pm}$ ), $\mathrm{Co}^{2+}$ (ionic radius $83.8 \mathrm{pm}$ ), $\mathrm{Cd}^{2+}$ (ionic radius $109.0 \mathrm{pm}$ ) and $\mathrm{Zn}^{2+}$ (ionic radius $88.0 \mathrm{pm}$ ) with respect to $\mathrm{Ni}^{2+}$ (ionic radius $83.0 \mathrm{pm}$ ). A brief comparison of $\mathrm{K}_{\mathrm{d}}$ values for the $\mathrm{Ni}^{2+}$ ions clearly demonstrates high adsorption in IIP and IIP2 in relation to NIP. Such results can be explained due to more porous surface of the IIP and IIP2 in detriment of NIP (Figure 2), which plays an important role in adsorption processes. Similar behavior can be observed for $\mathrm{Cu}^{2+}, \mathrm{Co}^{2+}, \mathrm{Cd}^{2+}$ and $\mathrm{Zn}^{2+}$ ions, where low $\mathrm{K}_{\mathrm{d}}$ values were observed in NIP. The selectivity coefficient (k) is of paramount importance to express the imprinting effect created in the imprinted polymers. As the stability of $\mathrm{Cu}^{2+}$ diamine complex is higher than $\mathrm{Ni}^{2+}$ - diamine complex, ${ }^{13}$ 
Table 4. Parameters related to imprinting effect $\left(\mathrm{K}_{\mathrm{d}}, \mathrm{k}, \mathrm{k}^{\prime}\right)$ of $\mathrm{Cu}^{2+}$ and $\mathrm{Co}^{2+}$ with respect to $\mathrm{Ni}^{2+}$

\begin{tabular}{|c|c|c|c|c|c|c|c|c|c|c|}
\hline \multirow{2}{*}{ Sorbent } & \multicolumn{2}{|c|}{$\mathrm{K}_{\mathrm{d}}\left(\mathrm{mL} \mathrm{g}^{-1}\right)$} & \multirow{2}{*}{$\mathrm{k}$} & \multicolumn{2}{|c|}{ k' } & \multicolumn{2}{|c|}{$\mathrm{K}_{\mathrm{d}}\left(\mathrm{mL} \mathrm{g}^{-1}\right)$} & \multirow{2}{*}{$\mathrm{k}$} & \multicolumn{2}{|c|}{$\mathrm{k}^{\prime}$} \\
\hline & $\mathrm{Ni}^{2+}$ & $\mathrm{Cu}^{2+}$ & & IIP/NIP & IIP/IIP2 & $\mathrm{Ni}^{2+}$ & $\mathrm{Co}^{2+}$ & & IIP/NIP & IIP/IIP2 \\
\hline IIP & 10938 & 2720 & 4.02 & & & 60795 & 20678 & 2.94 & & \\
\hline NIP & 118 & 1055 & 0.11 & 36.54 & 3.55 & 60 & 25 & 2.40 & 1.22 & 2.03 \\
\hline IIP2 & 8074 & 7138 & 1.13 & & & 17365 & 11975 & 1.45 & & \\
\hline
\end{tabular}

IIP = ion imprinted polymer synthesized in the presence of $\mathrm{Ni}^{2+}$ and surfactant; $\mathrm{NIP}=$ non imprinted polymer synthesized in the absence of $\mathrm{Ni}^{2+}$ and in the presence of surfactant; IIP2 = ion imprinted polymer synthesized in the presence of $\mathrm{Ni}^{2+}$ and in the absence of surfactant. The initial concentration of metallic ions was $5.0 \mathrm{mg} \mathrm{L}^{-1}$.

Table 5. Parameters related to imprinting effect $\left(\mathrm{K}_{\mathrm{d}}, \mathrm{k}, \mathrm{k}^{\prime}\right)$ of $\mathrm{Cd}^{2+}$ and $\mathrm{Zn}^{2+}$ with respect to $\mathrm{Ni}^{2+}$

\begin{tabular}{|c|c|c|c|c|c|c|c|c|c|c|}
\hline \multirow{2}{*}{ Sorbent } & \multicolumn{2}{|c|}{$\mathrm{K}_{\mathrm{d}}\left(\mathrm{mL} \mathrm{g}^{-1}\right)$} & \multirow{2}{*}{$\mathrm{k}$} & \multicolumn{2}{|c|}{$\mathrm{k}^{\prime}$} & \multicolumn{2}{|c|}{$\mathrm{K}_{\mathrm{d}}\left(\mathrm{mL} \mathrm{g}^{-1}\right)$} & \multirow{2}{*}{$\mathrm{k}$} & \multicolumn{2}{|c|}{$\mathrm{k}^{\prime}$} \\
\hline & $\mathrm{Ni}^{2+}$ & $\mathrm{Cd}^{2+}$ & & IIP/NIP & IIP/IIP2 & $\mathrm{Ni}^{2+}$ & $\mathrm{Zn}^{2+}$ & & IIP/NIP & IIP/IIP2 \\
\hline IIP & 93600 & 20466 & 4.57 & & & 46700 & 32820 & 1.43 & & \\
\hline NIP & 31 & 30 & 1.03 & 4.43 & 1.42 & 96 & 1864 & 0.05 & 28.60 & 1.74 \\
\hline IIP2 & 68550 & 21421 & 3.20 & & & 47093 & 58139 & 0.82 & & \\
\hline
\end{tabular}

IIP = ion imprinted polymer synthesized in the presence of $\mathrm{Ni}^{2+}$ and surfactant; $\mathrm{NIP}=$ non imprinted polymer synthesized in the absence of $\mathrm{Ni}^{2+}$ and in the presence of surfactant; IIP2 = ion imprinted polymer synthesized in the presence of $\mathrm{Ni}^{2+}$ and in the absence of surfactant. The initial concentration of metallic ions was $5.0 \mathrm{mg} \mathrm{L}^{-1}$.

it would be expected that larger $k$ values could be obtained for $\mathrm{Cu}^{2+} / \mathrm{Ni}^{2+}$ system in IIP and IIP2, if no imprinting effect was achieved. Nevertheless, as it can be seen in Table 4, the $\mathrm{k}$ value for the $\mathrm{Ni}^{2+} / \mathrm{Cu}^{2+}$ system of IIP (4.02) is higher than IIP2 (1.13) and NIP (0.11). Such results confirm that higher recognition sites exist in IIP than IIP2, while no recognition sites are present in NIP. The imprinting effect, quantitatively determined by relative selectivity coefficient, showed that the IIP for $\mathrm{Ni}^{2+} / \mathrm{Cu}^{2+}$ was 36.54 and 3.55 times more selective than NIP and IIP2, respectively. For the $\mathrm{Ni}^{2+} / \mathrm{Co}^{2+}$ system the imprinting effect observed was somewhat reduced, showing relative selectivity coefficient of 1.22 and 2.03 times greater than NIP and IIP2 (Table 4). The competition between $\mathrm{Ni}^{2+}$ and $\mathrm{Co}^{2+}$ for those selective sites of IIP can be explained due to very similar ionic radius of these metallic ions. Regarding to the $\mathrm{Ni}^{2+} / \mathrm{Cd}^{2+}$ and $\mathrm{Ni}^{2+} / \mathrm{Zn}^{2+}$ binary mixtures, the high adsorption affinity of recognition sites to the imprinted $\mathrm{Ni}^{2+}$ ions was once again confirmed from the great relative selectivity coefficient (Table 5).

As demonstrated, IIP presents good imprinting effect when compared with NIP and IIP2. However, in order to apply the enrichment method in real samples, the selective performance of the IIP towards $\mathrm{Ni}^{2+}$ ions in the presence of foreign ions $\left[\mathrm{Cu}^{2+}, \mathrm{Cd}^{2+}, \mathrm{Co}^{2+}, \mathrm{Sb}^{3+}, \mathrm{Pb}^{2+}, \mathrm{Mn}^{2+}\right.$ and $\left.\mathrm{Zn}^{2+}\right]$ at different proportions, was evaluated. For this task, $20 \mathrm{~mL}$ of $\mathrm{Ni}^{2+}$ ions solutions at $10 \mu \mathrm{g} \mathrm{L}^{-1}$ were preconcentrated under optimized conditions. The studied analyte:interferent ratios were 1:1, 1:10 and 1:100. The tolerance limit is defined as the foreign ion concentration causing an relative error smaller than $10 \%$ in the $\mathrm{Ni}^{2+}$ determination. Interferences may be caused by the competitive adsorption of ions onto IIP surface, however only $\mathrm{Pb}^{2+}$ interfered at level 100 fold to that $\mathrm{Ni}^{2+}$, leading to a decrease of analytical signal of $17.3 \%$, probably due to $\mathrm{Pb}^{2+}$ retention onto those non selective sites of the IIP (Table 6).

Table 6. Effect of foreign ions on the analytical signal recovery of $10 \mu \mathrm{g} \mathrm{L}^{-1} \mathrm{Ni}^{2+}$ submitted to preconcentration method

\begin{tabular}{lccc}
\hline Foreign ions & \multicolumn{3}{c}{ Recovery Percentage (\%)* of the Analytical Signal } \\
\cline { 2 - 4 } & \multicolumn{3}{c}{ Ratio analyte:foreign ion } \\
\cline { 2 - 4 } & $1: 1$ & $1: 10$ & $1: 100$ \\
\hline $\mathrm{Cu}^{2+}$ & 900.0 & 96.4 & 104.7 \\
$\mathrm{Cd}^{2+}$ & 103.4 & 104.0 & 100.8 \\
$\mathrm{Co}^{2+}$ & 104.4 & 94.9 & 103.9 \\
$\mathrm{Sb}^{3+}$ & 97.8 & 100.6 & 106.7 \\
$\mathrm{~Pb}^{2+}$ & 95.6 & 103.9 & 82.7 \\
$\mathrm{Mn}^{2+}$ & 98.4 & 96.3 & 100.0 \\
$\mathrm{Zn}^{2+}$ &
\end{tabular}

* Experiments carried out in triplicate

\section{Analytical characteristics}

The characteristic performance data for the IIP in the enrichment method under the optimum conditions were obtained by preconcentrating $20 \mathrm{~mL}$ of aqueous standard solution of $\mathrm{Ni}^{2+}$ ions. The calibration curve for $\mathrm{Ni}^{2+}$ ions 
was obtained in the range 0.5 up to $15.0 \mu \mathrm{g} \mathrm{L}^{-1}$ with satisfactory coefficient of correlation $(r>0.994)$. A limit of detection (LOD $=3 \mathrm{Std} / \mathrm{m}$, where Std is the standard deviation for ten replicates determination of the blank signal and $\mathrm{m}$ is the slope of the calibration curve) of $0.16 \mu \mathrm{g} \mathrm{L}^{-1}$ for $\mathrm{Ni}^{2+}$ was obtained, while the limit of quantification $(\mathrm{LOQ}=10 \mathrm{Std} / \mathrm{m})$ was found to be $0.55 \mu \mathrm{g} \mathrm{L}^{-1} .{ }^{22}$ Eight replicates determinations of both 2.0 and $13.0 \mu \mathrm{g} \mathrm{L}{ }^{-1}$ gave the respective relative standard deviation of $2.67 \mathrm{e} 3.37 \%$, respectively. By preconcentrating $20 \mathrm{~mL}$ of sample, the experimental enrichment factor of the proposed IIP sorbent, calculated as the ratio between the slopes of analytical curves with and without the enrichment procedure,,$^{23}$ was found to be 11 fold. Other important analytical parameters for sorbent enrichment were also calculated, such as consumptive index $(\mathrm{CI}=$ sample volume $/ \mathrm{EF})$ of $1.81 \mathrm{~mL}$ and enrichment efficiency (EE), which establishes the sensitivity enhancement using a preconcentration time of $1 \mathrm{~min}$. Thus, the EE was found to be $2.75 \mathrm{~min}^{-1}$. These satisfactory results related to the performance of solid sorbent enrichment reflect the outstanding application of hybrid organic-inorganic polymer in the development of sorbent preconcentration methodologies. Table 7 shows comparative data obtained by proposed method with other off-line sorbent preconcentration for nickel determination. Substantial improvements in sorbent preconcentration performance with the proposed method, such as low sample consumption, absence of chelating agent on the preconcentration procedure, high sample throughput and, mainly, selectivity are shown. It must be emphasized that improvements in the detectability of the method can be achieved by using higher sample volume.

\section{Real sample application}

The proposed enrichment method was applied to the determination of $\mathrm{Ni}^{2+}$ in water samples. In order to evaluate the feasibility of the method even in samples with high salt content, a synthetic seawater sample was prepared as follows: $27.9 \mathrm{~g} \mathrm{~L}^{-1} \mathrm{NaCl}, 1.4 \mathrm{~g} \mathrm{~L}^{-1} \mathrm{KCl}, 2.8 \mathrm{~g} \mathrm{~L}^{-1} \mathrm{MgCl}_{2}$, $0.5 \mathrm{~g} \mathrm{~L}^{-1} \mathrm{NaBr}, 2.0 \mathrm{~g} \mathrm{~L}^{-1} \mathrm{MgSO}_{4} \cdot{ }^{32}$ Lake water samples from Furnas Dam, Minas Gerais - Brazil, were collected

Table 7. Characteristic data obtained by selective sorbent preconcentration method using hierarchically hybrid organic-inorganic polymer and other offline sorbent preconcentration for nickel determination

\begin{tabular}{|c|c|c|c|c|c|c|c|}
\hline Sorbent & $\begin{array}{l}\text { Preconcentration } \\
\text { time (min) }\end{array}$ & $\begin{array}{c}\text { Sample } \\
\text { Consumption } \\
(\mathrm{mL})\end{array}$ & $\begin{array}{l}\text { Preconcentration } \\
\text { Factor }\end{array}$ & Samples & Technique & $\begin{array}{l}\mathrm{LOD} \\
\left(\mu \mathrm{g} \mathrm{L}^{-1}\right)\end{array}$ & Ref. \\
\hline $\begin{array}{l}\text { Polycarboxylic microsphere polymer } \\
\text { gel }\end{array}$ & 20,60 & 100,300 & 50,150 & $\begin{array}{l}\text { Mineral water, } \\
\text { seawater }\end{array}$ & GF AAS & 0.05 & 24 \\
\hline $\begin{array}{l}\text { Silica gel modified with } \\
\text { 3-aminopropyltriethoxysilane }\end{array}$ & 2.5 & 25 & 5 & Seawater & GF AAS & 0.5 & 25 \\
\hline Chromosorb-107 resin & 1.25 & 25 & 10 & $\begin{array}{l}\text { Electrolyte } \\
\text { manganese } \\
\text { samples }\end{array}$ & GF AAS & - & 26 \\
\hline $\begin{array}{l}\text { Nickel imprinted microbeads } \\
\text { (poly(EGDMA-MAH/Ni(II) } \\
\text { microbeads) }\end{array}$ & 100 & 100 & 20 & Seawater & FAAS & 0.3 & 27 \\
\hline Nickel imprinted organic polymer & 100 & 150 & 18.7 & Water samples & FAAS & 1.6 & 28 \\
\hline $\begin{array}{l}\text { Poly(vinyl chloride) modified with } \\
\text { 3-ferrocenyl-3-hydroxydithioacrylic } \\
\text { acid }\end{array}$ & 120 & 60 & 60 & Water samples & GF AAS & 0.41 & 29 \\
\hline $\begin{array}{l}\text { 2-(2-quinolinilazo)-4-methyl-1,3- } \\
\text { dihydroxidobenzene (QAMDHB) } \\
\text { followed by adsorption onto MCI GEL } \\
\text { CHP 20Y }\end{array}$ & 30 & 300 & 300 & $\begin{array}{l}\text { Rice, human hair, } \\
\text { water samples, soil } \\
\text { samples }\end{array}$ & GF AAS & 0.001 & 30 \\
\hline $\begin{array}{l}\text { Nickel imprinted amino-functionalized } \\
\text { silica gel }\end{array}$ & 66.6 & 200 & 100 & $\begin{array}{l}\text { Plant samples and } \\
\text { water samples }\end{array}$ & ICP OES & 0.16 & 31 \\
\hline Nickel imprinted organic polymer & 25 & 250 & 100 & Water samples & GF AAS & 0.05 & 20 \\
\hline $\begin{array}{l}\text { Nickel imprinted organic-inorganic } \\
\text { polymer }\end{array}$ & 4 & 20 & 11 & $\begin{array}{l}\text { Water samples } \\
\text { and phytotherapic } \\
\text { sample }\end{array}$ & GF AAS & 0.16 & $\begin{array}{l}\text { This } \\
\text { work }\end{array}$ \\
\hline
\end{tabular}

LOD = limit of detection; GF AAS = graphite furnace atomic absorption spectrometry; FAAS = flame atomic absorption spectrometry; ICP OES = inductively coupled plasma optical emission spectrometry. 
in polypropylene bottles, to which 3 drops of concentrated $\mathrm{HNO}_{3}$ for each $100 \mathrm{~mL}$ of samples were added in order to avoid growth of microorganisms. Afterwards, the samples were filtrated under vacuum using $0.45 \mu \mathrm{m}$ cellulose acetate membranes and buffered with $0.43 \mathrm{~mol} \mathrm{~L}^{-1}$ borate buffer (pH 8.4). Recovery experiments were carried out using sample solutions to which known amounts of $\mathrm{Ni}^{2+}$ ions solution had been added. Each recovery was calculated by comparing the results obtained before and after addition. As shown in Table 8 the data obtained for spiked samples showed good recoveries, thus attesting that the sorbent solid phase enrichment associated to GF AAS determination is a reliable way for enrichment of $\mathrm{Ni}^{2+}$ in various natural water samples as well as for sample clean-up. The direct analysis of $\mathrm{Ni}^{2+}$ in water samples containing high salt content, such as seawater could not be performed by GF AAS, because it generates high background signals, scattering, and a strong matrix effect that lead to a worsening on sensitivity and even loss of accuracy. Apart from the water samples, the method also was applied for $\mathrm{Ni}^{2+}$ determination in a phytotherapic product (Ginkgo Biloba) submitted to acid decomposition according to the literature. ${ }^{1}$ The amount of $\mathrm{Ni}^{2+}$ ions determined in Ginkgo Biloba was found to be $1.05 \pm 0.08 \mu \mathrm{g} \mathrm{g}^{-1}$, while the addition of $3.0 \mu \mathrm{g} \mathrm{g}^{-1}$ to sample gave rise to a recovery of $92.4 \%\left(3.74 \pm 0.09 \mu \mathrm{g} \mathrm{g}^{-1}\right)$.

Table 8. Recovery percentage for nickel ions determination in different kinds of water samples

\begin{tabular}{lccc}
\hline Samples & $\begin{array}{c}\text { Added amount } \\
\left(\mu \mathrm{g} \mathrm{L}^{-1}\right)\end{array}$ & $\begin{array}{c}\text { Determined } \\
\text { amount* }\left(\mu \mathrm{g} \mathrm{L}^{-1}\right)\end{array}$ & $\begin{array}{c}\text { Recovery } \\
(\%)\end{array}$ \\
\hline Tap water & - & $\mathrm{ND}$ & - \\
& 2.0 & $1.80 \pm 0.05$ & 90 \\
Lake Water & 4.0 & $4.36 \pm 0.26$ & 109 \\
& - & $\mathrm{ND}$ & - \\
Synthetic Seawater & 2.0 & $1.84 \pm 0.04$ & 92 \\
& 4.0 & $4.20 \pm 0.17$ & 105 \\
& - & $\mathrm{ND}$ & \\
& 2.0 & $1.99 \pm 0.14$ & 99 \\
& 4.0 & $4.04 \pm 0.02$ & 101 \\
\hline
\end{tabular}

$\overline{\mathrm{ND}}=$ not detected. $*$ The results are expressed as mean value \pm S.D based on three replicates $(n=3)$ determination. Confidence interval, $95 \%$.

\section{Conclusion}

Porous hybrid organic-inorganic polymer based on double imprinting concept for selective retention of nickel ions using 2-aminoethyl-3-aminobutylmethyldimethoxysilane (AAMDMS) as functional monomer was prepared, characterized against control blank polymers and successfully applied for nickel ions enrichment from aqueous solution. The chemometric tools based on factorial design and Doehlert matrix was successfully applied in the selection of optimal experimental conditions, helping to avoid trivial mistakes during optimization as well as leading to reduction of experiments. The results obtained in this study, based on relative selectivity coefficient, showed that IIP had imprinting effect for the $\mathrm{Ni}^{2+}$ in aqueous solution in comparison to IIP2 and NIP. The most selective performance of IIP is attributed to the double imprinting by $\mathrm{Ni}^{2+}$ ions and surfactant CTAB during predetermined orientation of those specific binding sites containing functional groups in selective cavities, which it is easily feasible in sol-gel process. It is worth to emphasize that the use of surfactant leads to the formation of polymers with more porous surface only in the presence of template $\mathrm{Ni}^{2+}$, as can be observed from smoother morphology of NIP. It indicates that there is a synergic effect between $\mathrm{Ni}^{2+}$ ions and surfactant in the pores formation.

Finally, it could be shown that with the present study, a more expanded application of hierarchically hybrid organic-inorganic polymer based on double imprinting concept in solid phase preconcentration is described, contributing for new investigations of these imprinted polymers in the field of analytical sciences.

\section{Acknowledgments}

The authors would like to thank CNPq (Conselho Nacional de Desenvolvimento Científico e Tecnológico), FAPEMIG (Fundação de Amparo à Pesquisa do Estado de Minas Gerais), CAPES (Coordenação de Aperfeiçoamento de Pessoal de Nível Superior) and INCT of Bioanalytical (Instituto Nacional de Ciência e Tecnologia de Bioanalítica) for the financial support and fellowships.

\section{References}

1. Barbosa, A. F.; Segatelli, M. G.; Pereira, A.C.; Santana Santos, A.; Kubota, L. T.; Luccas, P. O.; Tarley, C. R. T.; Talanta 2007, 71,1512 .

2. Rao, T. P.; Kala, R.; Daniel, S.; Anal. Chim. Acta 2006, 578, 105.

3. Tarley, C. R. T.; Arruda, M. A. Z.; Anal. Lett. 2005, 38, 1427.

4. Nishide, H.; Deguchi, J.; Chem. Lett. 1976, 5, 169.

5. Tarley, C. R. T.; Sotomayor, M. D. T.; Kubota, L. T.; Quim. Nova 2005, 28, 1087.

6. Andaç, M.; Ozyapi, E.; Senel, S.; Say, R.; Denizli A.; Ind. Eng. Chem. Res. 2006, 45, 1780.

7. Birlik, E.; Ersöz, A.; Denizli, A.; Say, R.; Anal. Chim. Acta 2006, 565, 145.

8. Makote, R. D.; Dai, S.; Anal. Chim. Acta 2001, 435, 169. 
9. Na, J.; Chang, X. J.; Hong, Z.; Qun, H.; Zheng, H.; Anal. Chim. Acta 2006, 577, 225.

10. Han, D. M.; Fang, G. Z.; Yan, X. P.; J. Chromatogr., A 2005, 1100, 131.

11. Burleigh, M. C.; Dai, S.; Hagaman, E. W.; Lin, J. S.; Chem. Mater. 2001, 13, 2537

12. Dai, S.; Burleig, M. C.; Ju, Y. H.; Gao, H.J.; Lin, J. S.; Pennycook, S. J.; Barnes, C. E.; Xue, Z. L.; J. Am. Chem. Soc. 2000, 122, 992.

13. Lu, Y.; Yan, X.; Anal. Chem. 2004, 76, 453.

14. Wu, G.; Wang, Z.; Wang, J.; He, C.; Anal. Chim. Acta 2007, $582,304$.

15. Tarley, C. R. T.; Silveira, G.; Dos Santos, W. N. L.; Matos, G. D.; Da Silva, E. G. P.; Bezerra, M. A. B.; Miro, M.; Ferreira, S. L. C.; Microchem. J. 2009, 92, 58.

16. Tarley, C. R. T.; Ferreira, S. L. C.; Arruda, M. A. Z.; Microchem. J. 2004, 77, 163 .

17. Jun, Z.; Zhi-Iiang, L.; Gang, X.; Xing, Z.; Trans. Nonferrous Met. Soc. China 2007, 17, 1367.

18. Canto, C. F.; Prado, L. A. S. de A.; Radovanovic, E.; Yoshida, I. V. P. Polym. Eng. Sci. 2008, 48, 141.

19. Hart, B. R.; Shea, K. J.; J. Am. Chem. Soc. 2001, 123, 2072.

20. Otero-Romaní, J.; Moreda-Pineiro, A.; Bermejo-Barrera, P.; Martin-Esteban, A.; Anal. Chim. Acta. 2008, 630, 1.
21. Jacob, R.; Tate, M.; Banti, Y.; Rix, C.; Mainwaring, D. E.; J. Phys. Chem. A, 2008, 112, 322.

22. Long, G. L.; Winefordner, J. D. Anal. Chem. 1983, 55, 712.

23. Tarley, C. R. T.; Arruda, M. A. Z.; Anal. Sci. 2004, 20, 961.

24. Dakova, I. G.; Karadjova, I. B.; Georgieva, V. T.; Georgiev, G. S.; Microchim. Acta. 2009, 164, 55.

25. Tokman, N.; Akman, S.; Ozcan, M.; Talanta 2003, 59, 201.

26. Yao, J.; Liu, Y.; Tuo, Y.; Zhou, F.; Zhang, J.; Xiao, Y.; Can. J. Anal. Sci. Spectrosc. 2004, 49, 267.

27. Ersöz, A.; Say, R.; Denizli, A. Anal. Chim. Acta. 2004, 502, 91.

28. Saraji, M.; Yousefi, H.; J. Hazard. Mater. 2009, 15, 1152.

29. Kiptoo, J. K.; Ngila, J. C.; Silavwe, N. D.; Microchim. Acta. 2008, 160, 211.

30. Yanga, G.; Fena, W.; Lei, C.; Xiao, W.; Sun, H.; J. Hazard. Mater. 2009, 162, 44.

31. Jiang, N.; Chang, X.; Zheng, H.; He, Q.; Hu, Z.; Anal. Chim. Acta. 2006, 577, 225.

32. Zougagh, M.; Rudner, P. C.; Torres, A. G.; Pavon, J. M. C.; J. Anal. At. Spectrom. 2000, 15, 1589.

Received: February 21, 2009

Web Release Date: December 3, 2009

FAPESP helped in meeting the publication costs of this article. 